\title{
THE EARLIEST GENERATION OF MISSIONARY PHOTOGRAPHERS IN WEST AFRICA AND THE PORTRAYAL OF INDIGENOUS PEOPLE AND CULTURE*
}

\author{
Paul Jenkins \\ Basel Mission and \\ University of Basel
}

That photographs have been neglected in the study of African history has become, in recent years, a well-established truism. ${ }^{1}$ To take one point of entry into the literature which has set out to correct this deficiency: a Seminar held in SOAS in 1988 on "Photographs as Sources for African History" amply confirmed this point (Roberts 1988). The papers and discussions indicated the scope-and the problems - of some of the well-known and less well-known, holdings in this field. They also showed, however, that a number of scholars had already devoted considerable thought to the implications of historic photographic holdings for the pursuit of historical and anthropological studies not only in colonial history but also in African history per se. A similar point of entry for the German-speaking world is provided by the literature accompanying an important exhibition which toured a number of West German museums in 1989. "Der geraubte Schatten" concerned itself with the history of photography in the whole non-European world (Theye 1989; Ueber die Wichtigkeit 1990; see especially the essays by Wagner and Corbey for reflections on missionary photography).

The involvement of the Basel Mission's photographic holdings in research on non-European history mirrors this patchy "state of the art." The Basel Mission-like all missionary societies?-placed a higher value on words than pictures in the past, so that its pre-1914 photographic holdings are much less well ordered than its documents. But since the early 1980s a series of queries from outside have forced us to become increasingly aware of the scope and nature of our collection. The estimate for the number of photographs we possess from all parts of the world, and dating broadly from 1860 to 1945 , has had to be continually revised upwards, now standing at what is probably the final figure of $c a$. 50,000 images, including several thousand original glass-plate negatives from before 1914, and several thousand lantern slides. Financing for the current effort to catalog the collection and publish it in an interactive system using the electronic storage of images (Frey Näf 1990 ) has also come, to the tune of more than $80 \%$, from outside the Basel Mission. And while one part of the collection has played an important part in what is, surely, at the moment, the best-developed analysis of photographs in the context of African history-Christraud Geary's work on the kingdom of Bamum in the German colonial period (Geary 1988, etc)-the contents and

History in Africa 20 (1993), 89-118. 
significance of other parts of the collection are still very uncertain.

This paper emerges from the praxis of work with photographs in our archive. It concerns itself firstly with one aspect of the chronology of mission photography, the search for the first generation of mission photographers in West Africa, and discusses some of the general implications of what has been established so far about this question in our holdings. The second part of the paper takes up the work of one of the earliest photographers, Christian Hornberger, a missionary of the North German or Bremen Mission. It concentrates on the information about photography, and the use of illustrations, in one European missionary publication, the Monatsblatt der Norddeutschen Mission (hereafter $M B$ ) between 1863 and 1888, looking in particular at the interaction between photography as an activity in the context of a missionary organization and the perception of the social environment in which the missionaries worked.

\section{II}

It was about 15 years ago that we first realized in Basel that we have some 'vintage prints' in our photographic holdings dating from the late $1850 \mathrm{~s}$ or early $1860 \mathrm{~s}$. In the course of her work investigating miscellaneous uncataloged papers of uncertain origins in the Archive, Sibylle Schamböck, at that time a member of staff, realized that a handwritten document entitled "Photogramme," dated 1860, and signed by the missionary C.G. Richter, in fact described a series of pictures which corresponded exactly with an undated and uncataloged photo album from India in our holdings. ${ }^{2}$ Roughly at the same time we realized that a photograph in a similar album from Ghana included a portrait of a little girl called Wilhelmina Locher, whom we knew, from our Familienregister, was born to missionary parents in Akropong on 8 April $1858 .{ }^{3}$ These were important findings - at that stage we had had only a vague apprehension that some of our photographs must date back to before World War I.

In 1989 it proved possible to arrange finance for Timothy Garrard to come to Basel for a month and work on the ordering and identification of our Ghana photographs. Taking up the hint that we were likely to have very early (pre1885) Ghana photographs in our collection he made parallel preparatory investigations in our library and archive holdings of photographs, images printed in German mission publications, other references to photography in Ghana in these years in German mission publications, and references to photography in our MS holdings. His conclusions are described here, supplemented at one or two points by investigations I myself have carried out since.

The earliest evidence in these sources of someone taking photographs in a mission context on the territory of the present-day state of Ghana comes from 1856, when the Scottish Methodist pastor Daniel West visited West Africa, carrying a daguerreotype camera with him, which he used to take photographs in Cape Coast. (He had already used his camera in Bathurst and went on to 
take photographs in Lagos and Abeokuta). A few of his images were printed as engravings in the account of his travels published posthumously in English (West 1857). The Calwer Missionsblatt published one of West's images in 1859 , with a translated description of the situation in which the photograph was taken, and gave the date of the letter in which this event was reported. The text makes it clear that the image was originally a daguerreotype (Calwer Missionsblatt, September 1859, 64). ${ }^{4}$

The earliest evidence Garrard found for Basel Mission interest in photography in Ghana dates from 1857, when the missionary Wilhelm Locher both asked to be equipped with a camera, and brought seven photographic views back with him to Europe when he came on leave (Basel Mission Archive, Committee Minutes 1857, meetings of 15 June and 29 July). The provenance of these images is, as yet, uncertain, and it is also not yet clear whether we still have them in our collection. ${ }^{5}$ In 1860 Locher was himself equipped with a camera, worked with it over the years 1860 to 1867 , and sent back several dozen photographs which were pasted into the album mentioned above in which his daughter Wilhelmina appears. ${ }^{6}$

In 1863 the North German Mission equipped their missionary Christian Hornberger with a camera. The few letters from Hornberger which refer to technical problems with photography indicate that he was probably using the wet-plate collodium process. (The process he used was similar enough to that used by Locher to allow the two to exchange tips on how to practice photography in their part of the tropics). ${ }^{7}$ Hornberger was producing stereo images by 1866 .

This listing of three photographers working in a missionary context in Ghana in the decade and a half after 1856 is suggestive but provisional. It is suggestive in the sense that we seem to be demonstrating a trend: photography as an instrument which missionary societies were taking up at this time even in a hostile and dangerous environment like that of the West African coast. It is provisional in the sense that it is based only on holdings in the Basel Mission Archive and Library, and some investigation of parallel holdings in Bremen. One might argue that West was not a typical member of the Wesleyan Methodist Missionary Society. ${ }^{8}$ If so, what we have is merely an interest in photography on the part of two closely-linked German organizations, and not proof of a general interest in photography on the part of missionary societies. ${ }^{9}$ This view would not be altered by one of the main discoveries made about early photography in our Archive since Garrard's pioneering investigation: it turns out that in the 1850s future missionaries in training in the Basel Mission Seminary could take instruction in photography; it was under these auspices that Locher, Hornberger, and Richter learned this skill. ${ }^{10}$

A lot depends on what future investigation may show about the history of photography in the Church Missionary Society. ${ }^{11}$ Nevertheless, one response to an early presentation of this paper indicated that an open-ended and optimistic attitude to the likelihood that missionary societies concerned themselves with photography in the third quarter of the nineteenth century is not misplaced. Françoise Raison informed me about her studies of missionary 
photography in Madagascar, in which it is clear that photographs were already being taken in the context of the London Missionary Society and Jesuit presence in the 1850s. Early indications of an interest in photography among missionaries in East Africa are also beginning to offer themselves. Gottfried Deimler, a Basel-trained missionary who was recruited by the CMS, who traveled to Bombay en route to joining Rebmann in Kusuludini in 1854-55, had learned photography in Stuttgart in 1854. And the English Methodist Charles New printed some engravings based on his own photographs in his descriptions of travel in East Africa published in 1873 (New 1873). ${ }^{12}$

There is, in any case, a systematic train of thought which would lead us to expect missionary societies to take an interest in photography sooner rather than later. They are in one sense communications systems linking people in the West with situations in the non-western world, and depending on the financial commitment of their supporters at home. A change in communications technology would be likely to interest at least some of them. At this stage of the study of missionary photography, when we are reflecting on recently rediscovered holdings of early photographs, and wondering about the possibility of more to come, we should consider it likely that any missionary society was organizing itself a supply of photographs from overseas in the third quarter of the nineteenth century.

"Organizing a supply" can, of course, also mean purchasing photographs from studios, where these existed, or obtaining images from other missionary societies. It is my impression that there was frequent exchange of objects, images and texts among Protestant missionary societies for use in their publicity into the 1860 s and 1870 s, if not throughout the century. It may be true as well that any missionary society which existed at that time, and which has not since suffered major damage through war or economic collapse, may well be in the kind of situation which has obtained in Basel, where persistent and well-informed queries can lead to the rediscovery of photographic holdings dating back to the third quarter of the nineteenth century.

\section{III}

Where, however, are the many images one would expect to find if missionary photography was so much more widespread in the pre-1885 period than we have realized so far? Even in Basel it seems clear that more photographs were taken than we have vintage prints in our holdings, and there must be a real likelihood that in other centers far more photographs will have been lost than has been the case here.

The answer to this question is probably to be found in the many engravings of African scenes published in mission literature in the second half of the nineteenth century. The techniques by which a photographic image can be transferred mechanically into print were only becoming a practicable prospect for missionary publishers $\mathrm{ca}$. 1890, to judge by Basel and Bremen Mission publications. Before 1890 photographs were being published as engravings. ${ }^{13}$ As our knowledge of surviving holdings of early photographs grows, there- 
fore, so will the number of engravings which we can identify as having been based on photographs. To take an example pertinent to this paper: all eighteen photographs published in $M B$ between 1884 and 1888-most, perhaps all of which, still exist as vintage prints-were actually published as engravings. Moreover, as our knowledge of references to photography in mission literature and mission archives grows, so will the number of engravings increase where we can judge the probability that a specific image is based on a photograph which we know once existed.

Of course, engravings need to be assessed with an especially critical eye, once we begin to look at them as quasi-photographical sources. The image had to be transcribed onto a block of some kind (the presumption is that in most cases wood was used), which means that a craftsman intervened between the direct mechanical registration of an image in a photograph and its publication, and that changes therefore could be made in the image for a variety of editorial reasons. ${ }^{14}$ Nevertheless, it will obviously be possible to build up quite a large number of direct comparisons between a photographic original and the engraving as published. One pair of images was published in Jenkins and Geary (1985:60) to establish how closely engravings did follow photographic originals, but looking back I would say that the presentation of details there was inferior to other engravings where a comparison with the original photograph has since been possible (for example, figures $4 b$ and $5 b$ below). Gascoigne (1986) remarks on the accuracy of many nineteenth- century engravings depicting European works of art. He also reports that, in a process he calls photoxylography, photographic emulsion was spread on the wooden block which was going to be used for the engraving, and the image was then photographed onto it. There is good reason for approaching engravings in this field with some confidence that the technicians involved could, and often did, work accurately right down to the depiction of small details.

In the meantime I have tried to see if it would be possible to put together a list of criteria for judging whether the engraver was working from a photograph or not, purely by looking at the printed image, and with no reference to supporting documentation which is in any case often missing or very hard to locate. I have found that generalizations are difficult and that we shall probably have to go though a phase in which researchers interested in individual engravings assess the likelihood that a specific image was drawn from a photograph. Obviously, in view of exposure times and the sheer cumbersomeness of photography as a process before the 1880 s, no engravings containing rapid or dramatic movement, or images apparently derived from a hostile situation, can have been based on a photograph. Even there, however, one has to be careful. It was possible from the beginning of the photographic history of West Africa, to create posed images suggesting action-already in the 1860 s we have a Hornberger photograph of women, their pestles poised above their mortars, to illustrate the production of fufu. ${ }^{15}$ I do wonder, however, whether the new quality of images produced by photography did not call forth new techniques of shading in engravings-it seems to me to be very possible, for instance, to distinguish between an engraving based on a line-drawing and one 
based on an original, where the whole surface of the image contains signals as to how light fell on the objects photographed.

One other major subject for investigation is the question of continuity and change over the period in which photography was introduced as a technique in missionary communications. Illustrations in mission publications do not begin with the availability of photographs, but go back to the end of the Napoleonic Wars, when at least four periodical publications started, intended for the less well-educated and featuring an engraving with an interpretative essay on the title page of each new number. ${ }^{16}$ Presumably, as well as "importing" images which had been produced in other contexts, such pre-photographic mission publications were using images based on sketches made by missionaries. ${ }^{17}$ Conventions were presumably established in missionary illustrations well before the development of photography. What happened to those conventions once photographs were available? And what happened to the Missions' artists in the field? Did they switch to photography, once this new medium became available, or did they continue to produce images "by hand"?

Photography, especially with a slow camera, and in situations where the human object could help to determine how he or she was pictured, was much less likely to be sensationalist in its content than images which were generated by artists or by technicians at the request of editors in a metropolitan context. ${ }^{18}$ One could probably identify a category of simplified ideologized images which established themselves in the first half of the nineteenth century (Josenhans n.d. would be a prime case of this kind of image, with its colorful, not to say lurid, illustrations of the evils out of which mission rescued people). So-what changes can one identify in illustrations and their use once photographic images were available? Did they perhaps become more sober? In the meantime I would suggest that engravings in missionary literature showing objects, views, groups of people and individual portraits which are not clearly based on line drawings and whose first publication date lies later than 1850 may well have been based on photographic originals.

It is not my intention to cause a kind of South-Sea Bubble of speculation about the size of early photographic holdings for African history in general, or African church history in particular. The widely-made observation that the commercially-prepared negative plate made photography much more practicable from the 1880 s is not likely to be overturned. And it is seems to be true that in the 1870s, once the pioneers had withdrawn from this activity, neither in the Basel nor in the Bremen Mission in West Africa was photography pursued with any great vigor. ${ }^{19}$

Nevertheless, at this stage, and following up the findings and suggestions made by Vera Viditz-Ward after her investigations of early photography in Sierra Leone (Viditz-Ward 1987), it is worth arguing that in principle it is possible that a camera was part of the European presence anywhere in Africa from the $1850 \mathrm{~s}$ on. By this assumption, a camera may have been present over perhaps two-thirds of sub-Saharan Africa during the first phase of contact between Europeans and Africans. This paper concerns itself with mission photography and with the role of photography in the missionary perception of 


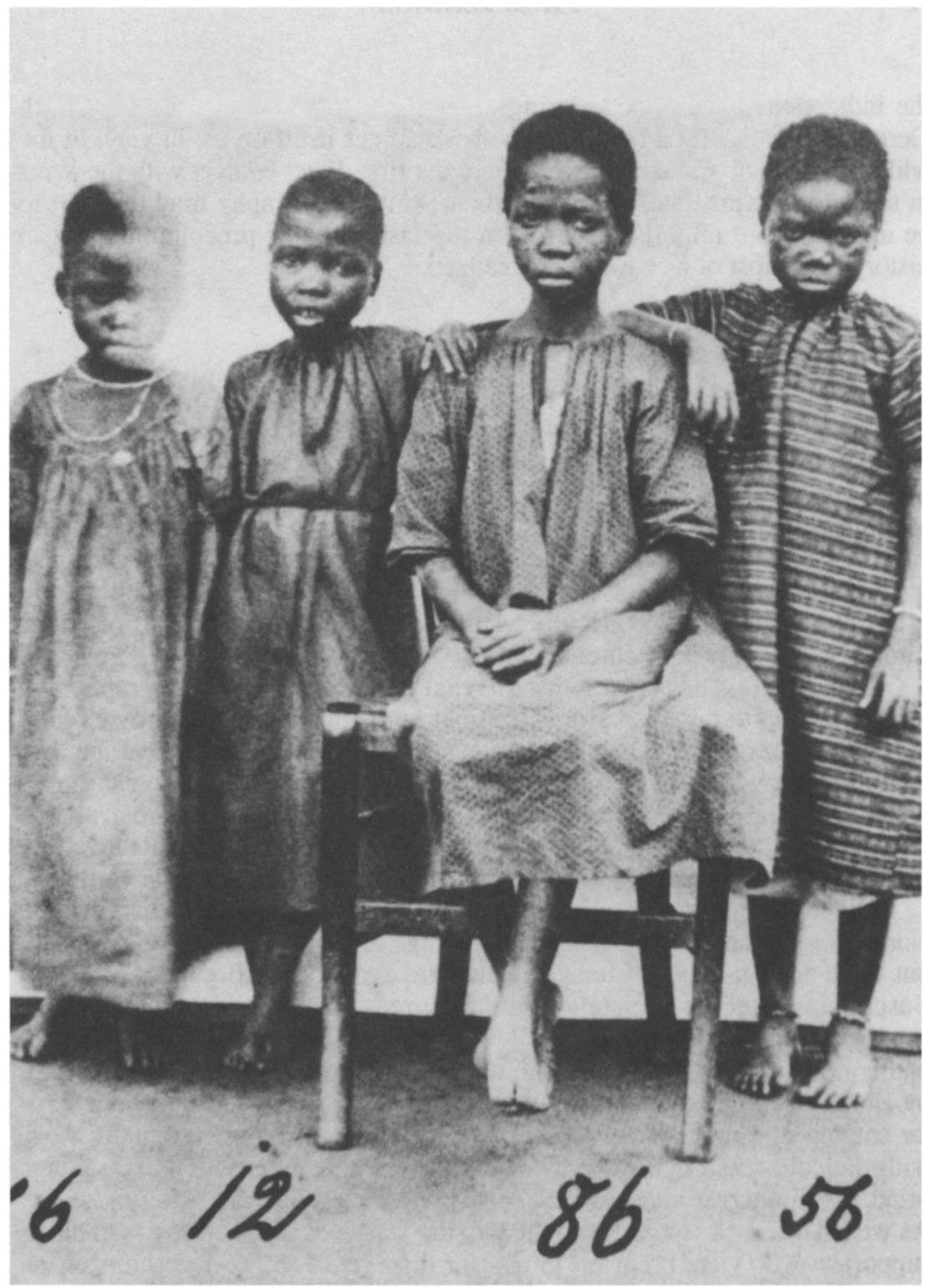

Figure 1

North German Mission deposit in the Bremen Staatsarchiv 7, 1025-108/3. "Freed Slave Children in Anyako." A typical photograph of freed slave children from 1863 or 1864 . The numbers are a key to their names; see the lists in Zahn 1864, 1865, and 1866. The little girls' clothes are surely of European origin, though the one on the left seems to have two necklaces, and the one on the right two anklets and a bracelet. These are presumably of indigenous origin. Supporters of the North German Mission were still religiously donating clothes to the Mission in the 1880s, which were presumably being taken to their converts in West Africa (see the regular lists of donations and donors in $M B$ ). By $1888 M B$ was prepared to acknowledge that the indigenous cloth was worthy of Sunday, but hardly practicable clothing for work; see $M B 1888120-22$, a portrait of two indigenous "workers" in their best Sunday clothes. 
the indigenous environment during one episode in the history of the North German Mission. But a broader hypothesis forces itself on us: in view of the wide tracts of sub-Saharan Africa where the first direct contact with the West in any of its forms dates from later than 1850 , photography may turn out to be a much more important source on the last phase of precolonial African history than most of us have so far realized. ${ }^{20}$

\section{IV}

Of the early mission photographers working in West Africa whose images are to be found in our Archive, Christian Hornberger is the one whose work is most accessible and rewarding at the moment from the point of view of an analysis of its contents. Hornberger, who was trained in the Basel Mission House but appointed missionary by the North German Mission, first arrived in the Ewe-speaking area of southeastern Ghana in 1858. ${ }^{21}$ As we have seen, he began taking photographs there in 1863 , and probably continued to use his camera until 1869. He died, still in West Africa, in 1881. (For a new summary of his life see Schrenk 1990).

Although it is possible to discuss vital questions about photography and its relationship to missionary organizations and indigenous culture by looking at Hornberger's photographic work, it is also important to make clear the limitations under which the discussion has to labor. Obviously work on any photographer is most adequate and persuasive if all his photographs are available for study, and if they can all be fully documented. Analyses at this level are not possible for Hornberger, however, and almost certainly never will be.

The main repositories of Hornberger's photographs are the archives of the North German and Basel Missions. Holdings in the two collections overlap, but there are a number of images which are available in Bremen and not in Basel. ${ }^{22}$ In Basel the completion of our current project for a comprehensive cataloging of our photographic holdings should provide the basis for a full listing both of those photographs in our holdings which were definitely taken by Hornberger, and those which can probably be ascribed to him. But a similar cataloging program in Bremen, a necessary prelude to systematic work with the collection, is not yet planned. Furthermore, it is likely that vintage prints of Hornberger images are widely spread in the German-speaking world. As we shall see, the North German Mission was offering such prints to all its supporters who were prepared to pay for them. And Hornberger himself, on furlough in Europe in 1866, was promoting sales himself, for example, by getting a contact at the court in Stuttgart to show them to the Queen of Württemberg. ${ }^{23} \mathrm{At}$ the moment, therefore, an analysis of Hornberger's oeuvre concerns itself with several dozen images, but these are not necessarily all those which reached Europe, let alone all those he took in West Africa.

The documentation of the photographs-when and where he photographed whom or what, and for what reasons-may never be more than partly complete, to judge by my own attempt to locate relevant material in the North German Mission archival holdings in the Bremen Staatsarchiv. It seems 


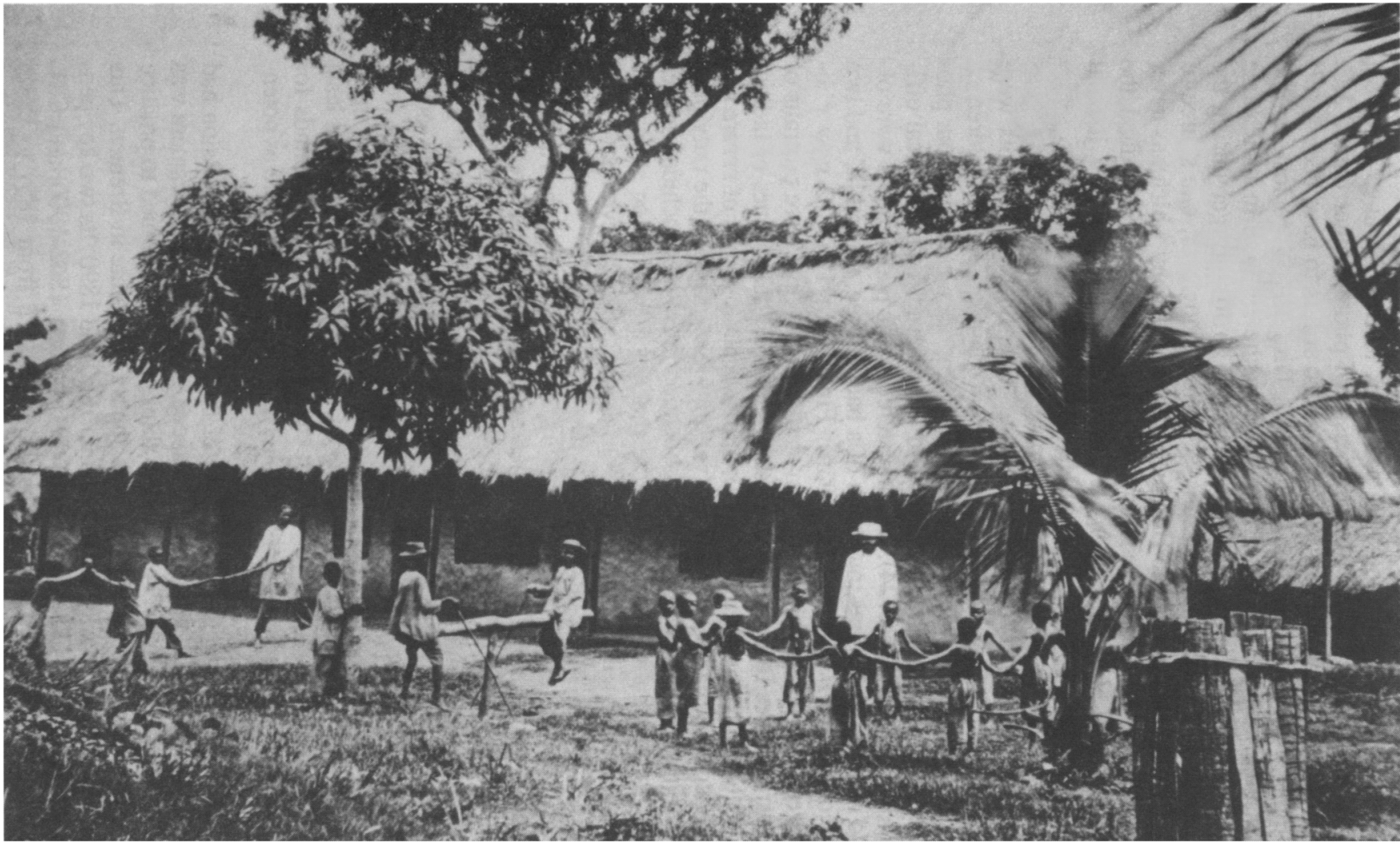

Figure 2

North German Mission deposit in Bremen Staatsarchiv. "The Old Mission Station in Ho, ?with Missionary G. Hess"? reference number 7, 1025-109/35. An image redolent of the early phase of Hornberger's photography: ex-slave children (presumably) enjoying European children's games in front of a Mission building. 
unlikely that all Hornberger's letters addressed to the Bremen Mission leadership accompanying photographs sent back to Bremen have survived. Hornberger was being advised by a professional photographer named J.C. Herzog and that exchange of correspondence also seems to have been lost. ${ }^{24}$ The minutes of the North German Mission's Directorate are lost for the relevant period, and there is no obvious file in the Archive in which one might expect to find letters from the Directorate to Hormberger during the years when he was taking photographs. ${ }^{25}$ There is, however, one source of information on the background to Hornberger's photography which has never been analyzed from this angle: the main North German Mission periodical, the Monats-Blatt der Norddeutschen Mission (MB), the monthly journal distributed to its supporters. The data in $M B$ can be summarized briefly.

In 1863 Hornberger was asked to take photographs which could be sold as prints to North German Mission supporters. Three batches of prints were specifically offered for sale. In 1864 seven group photographs of children on Bremen Mission Stations were offered, plus a portrait of a catechist, four photographs of the Mission Station in Ho, and two of traditional political officials ( $M B$, September 1864:724). In 1866 stereoscopic photographs were offered, two of mission stations, one each of a baobab tree, an anthill, and two African workers ( $M B$ March 1866:803n). Finally, in 186812 new photographs were offered for sale, 9 of them stereoscopes. Five were portraits of Christians and scenes from the mission station in Ho; three scenes of indigenous life (eating, grinding corn, pottery); and five photographs of nature and natural products ( $M B 1868: 929)$. These were quite clearly not the only photographs Hornberger took, however. The collection in Bremen includes images not offered for sale in $M B$, and it is clear that Bremen Mission supporters could order these as well, if they knew about them. They may even have been able to ask for specific other pictures to be taken. ${ }^{26}$

Once Hornberger stopped taking photographs in 1869, more than a decade went by before photographs were mentioned again in $M B .{ }^{27}$ And it really does seem that photography had been dropped as an activity in the North German Mission over this period. From 1884 to 1888 , however, $M B$ published a notable series of 18 explanatory essays on engravings depicting scenes on its West African mission field. Perhaps as many as 15 of these engravings were based on photographs taken by Hornberger. These essays were written up to 20 years after the photographs had been taken, and were posthumous, at least as far as Hornberger was concerned. But there are substantial grounds for incorporating them in any analysis of Hornberger's photographs here as potential documentation on the original significance of each image.

As will become clear, the Directorate of the North German Mission had first oriented Hornberger's view-finder to specific images when a camera was sent him in 1863 . There is every reason to think that he continued to practice photography in close contact with the Mission's Directorate in Bremen. This directorate was extraordinarily stable between 1860 and 1890 . Its two key people were Inspector F.M. Zahn, who held this position 1862-1900, and C.R. Vietor, Chairman of the Committee and Editor of $M B$ from 1851 to 1888. 


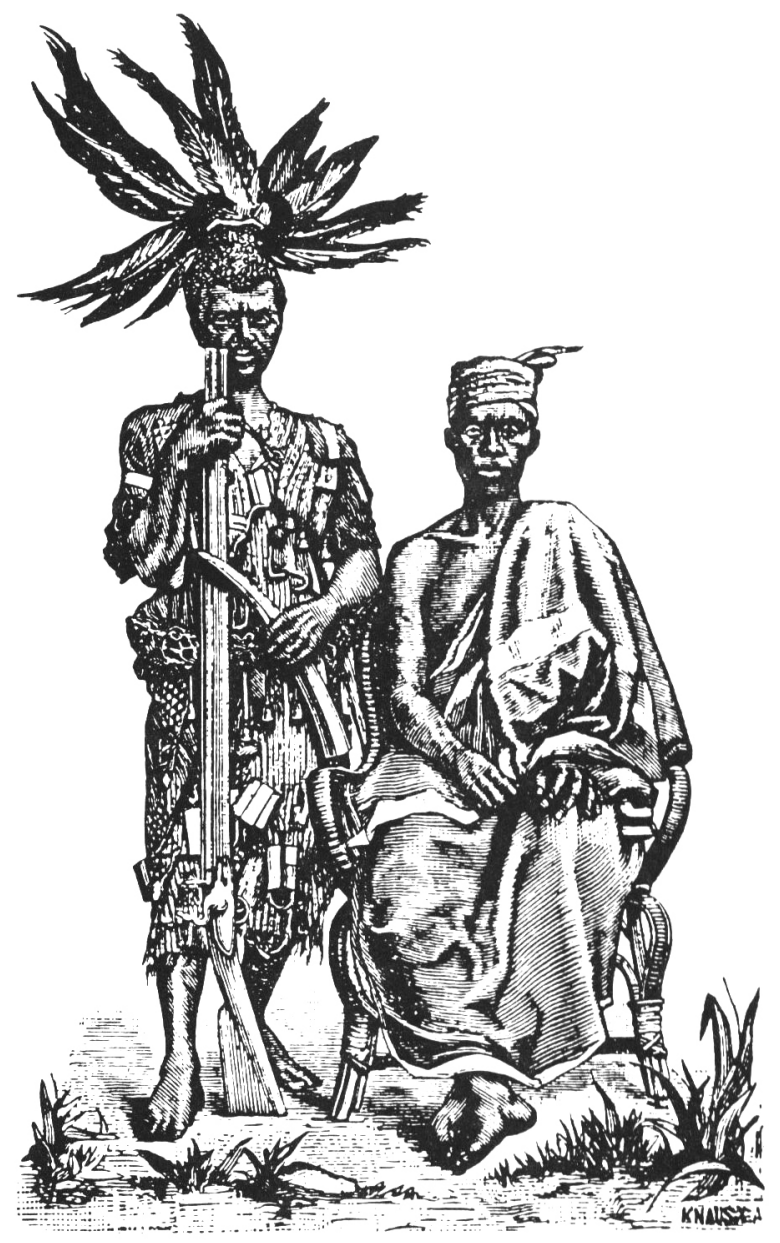

Figure 3

The King of Ho's speaker and his bodyguard. Engraving made after one of the Hornberger photographs offered for sale in 1864 (a vintage print is at QD-30.014,44 in the Basel Mission Archive) and published in $M B$ 1885, 138-41. This image stresses the alienness of the Mission's indigenous social environment in Eweland. 
And indeed, the $M B$ breathes continuity right through the $1860 \mathrm{~s}, 1870 \mathrm{~s}$, and 1880 s, frequently recalling how the North German Mission has got to the position it now occupies in West Africa, and its explanations seem very consistent over time. ${ }^{28}$ Under these conditions it is not unreasonable to pay attention to the possibility that commentaries published in the 1880 s reflected attitudes to photographic images as they were being produced in the 1860 s.

Hornberger's images, judging by those listed for sale in $M B$, fall into three thematic groups: depicting the work of the Mission, the natural environment, and indigenous life. At first sight there is no chronological change of emphasis between these themes-the first and the third are both represented in the images offered for sale in 1864 and 1868 - and there is probably no special significance to be drawn from the fact that the second theme appears for the first time in 1865.

Examination of the actual images of the work of the Mission and of indigenous life, on offer in 1864 and 1868, however, does indicate two very significant changes in the way these thematic groups were handled. To take the portrayal of the work of the Mission first: in 1863 more than half the images of mission work were group portraits of named children and young peopleand the more general scenes of life on the mission station all included such figures at work in different ways (see Figures 1 and 2). In 1868 such images are not on offer.

Taking, then, photographs of indigenous life: those on offer in $1863 \mathrm{fit}$ into the well-known category of images emphasizing the alien nature of the stranger, the Other (der Fremde) (Figure 3). In 1868 the theme of strangeness is perhaps not totally absent, but activities and products are shown to which the Mission's supporters could well have felt some degree of identification, especially if they came from a rural setting - a family eating, ${ }^{29}$ a woman grinding corn, locally-made pottery (see Figures 4 and 5). I suggest that these changes reflect both the history of the North German Mission in Southeastern Ghana in the 1860s and the double role which photography could play in a mission context: reinforcing familiar messages by offering appropriate images on the one hand, but also, because of its own unavoidable parameters, nudging people into taking a fresh look at their environment.

In the late 1850s the North German Mission adopted a policy of buying "slave children" into freedom. This was partly a tactic to overcome the anomie from which the missionaries were suffering - they had evidently not yet found a way to approach local people which would result in the kind of response they could recognize and take up. The scheme had considerable significance for the Mission's connections with its supporters at home. Groups and individuals in Germany and Switzerland were offered the opportunity to take financial responsibility for the purchase of a single child. They could then name the child, and provide support for it in other ways. Something of the order of 120 children came into the hands of the Mission in this way. ${ }^{30}$

This policy was probably the main reason for the North German Mission's decision to start photography on its mission field in West Africa. The children and young people with their identifying numbers (e.g., figure 1) 
were in fact freed slaves. The numbers corresponded to those in lists published in the early 1860 s by the Mission (Zahn 1864, 1865, 1866). An extended meditation published as editorial material in $M B$ (September 1863:665-66), when the first photographs arrived in Bremen, explicitly linked photography to the interest of many North German Mission supporters in individual children in a dramatic way:

Those who have bought children free and sewn them jackets and
frocks certainly never dreamed that they would see the children wear-
ing these clothes-but there they are, at least as a picture! And how
nice they look, especially little Petrus Neuenkirchen!... and what
emotions one feels, in one's heart of hearts, when one looks at these
pictures and thinks that, just a few years ago, these children knew
nothing of the Lord, and were, most of them, poor slaves. What a
fate they would have had! But now, there they are, in Christian care,
bought free by love, clothed and being educated.

The scheme had to be broken off in 1867-68 - that is, no more children were bought free. This was announced publicly and other public signals were given in $M B$ that all was not well. The problem seems to have been that very few of the children came to correspond to the kind of people which the Mission and its sponsors in Europe had imagined they would. The image of a cruel and loveless Ewe culture implied by the scheme (few things could be worse than selling children!) was wide of the mark, as was the Mission movement's own self-image as people offering a community of such self-evident love and worth that the children would enter it with no serious backward glances. Instead, the Mission had constant problems with many of the children. The reductio ad absurdum was that some had to be forcibly brought back to the Mission station when they ran away, and in other cases the Mission formally declared they were giving up their interest in a child, which meant that it returned to being a slave in an indigenous family (Ustorf 1986:211-12, not least quoting $M B$ 1875:1366).

It needs no very sensitive eye to see the implications of the sponsors' disappointment for the North German Mission. The story of the freed slave children re-echoes in $M B$ at least into the 1880s, with reference to those ex-slave children who had, in the sense of the North German Mission, made good, (for example the Catechist Christian Aliwodso), ${ }^{32}$ and to the many who maintained a careful distance from the mission stations in their adult lives. ${ }^{33}$

It is evident that under these circumstances portraits of the ex-slave children would no longer be offered for sale by the North German Mission in 1868. But the early general scenes of mission station life were also under a cloud. Not only did they often depict named children and adolescents who by the late 1860 s were no longer obediently doing what they were told. They also demonstrated an innocence about the whole question of applying European customs to West African situations which may have been coming to worry reflective people, pictures of African children on a seesaw, for instance, or playing ring-a-ring-a-roses (figure 2). 


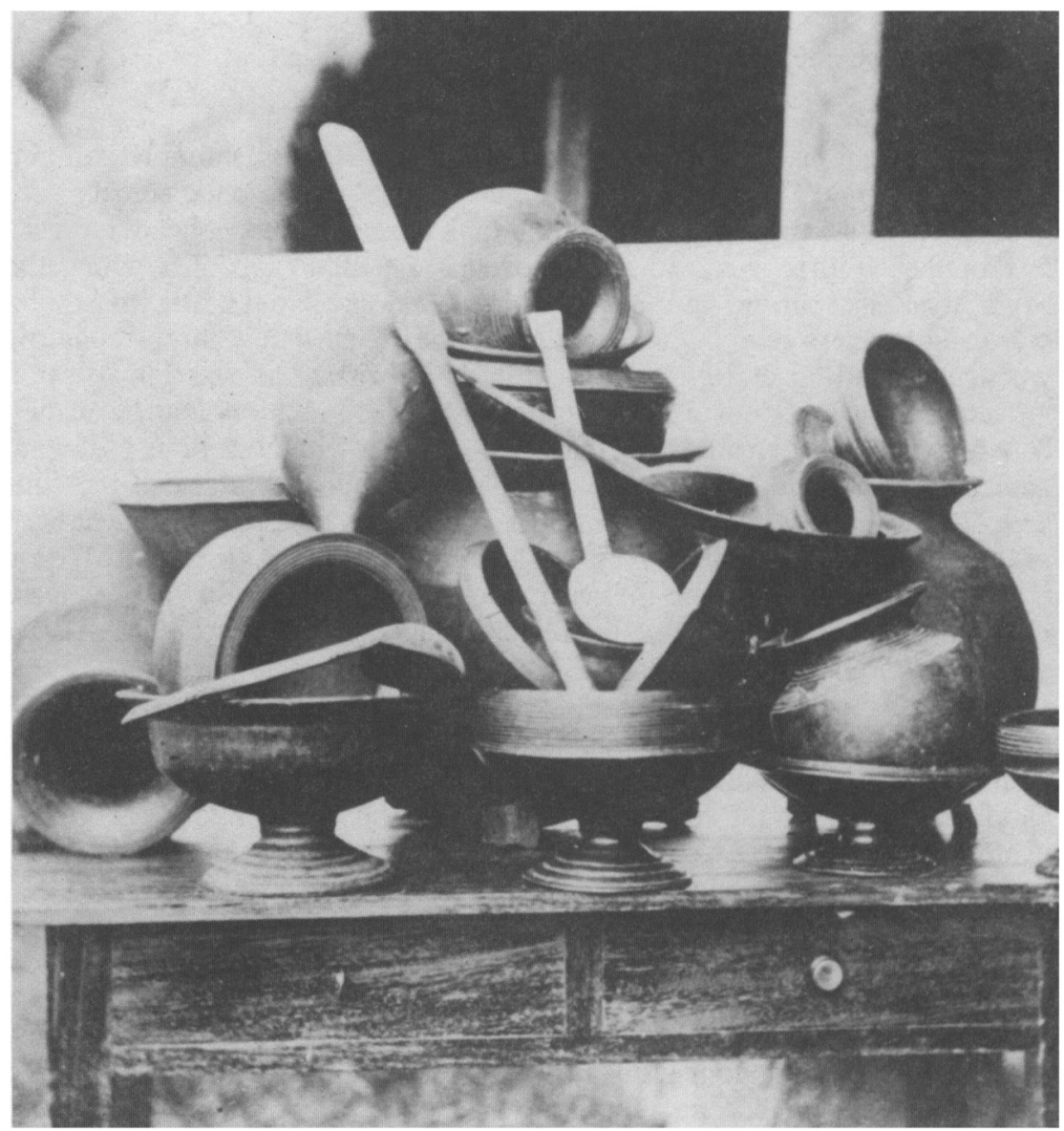

Figure 4a

Basel Mission Archive, QD-30.01454. A photographic still-life composed of indigenous pottery and other domestic utensils. This image was offered for sale as a print in 1868. 


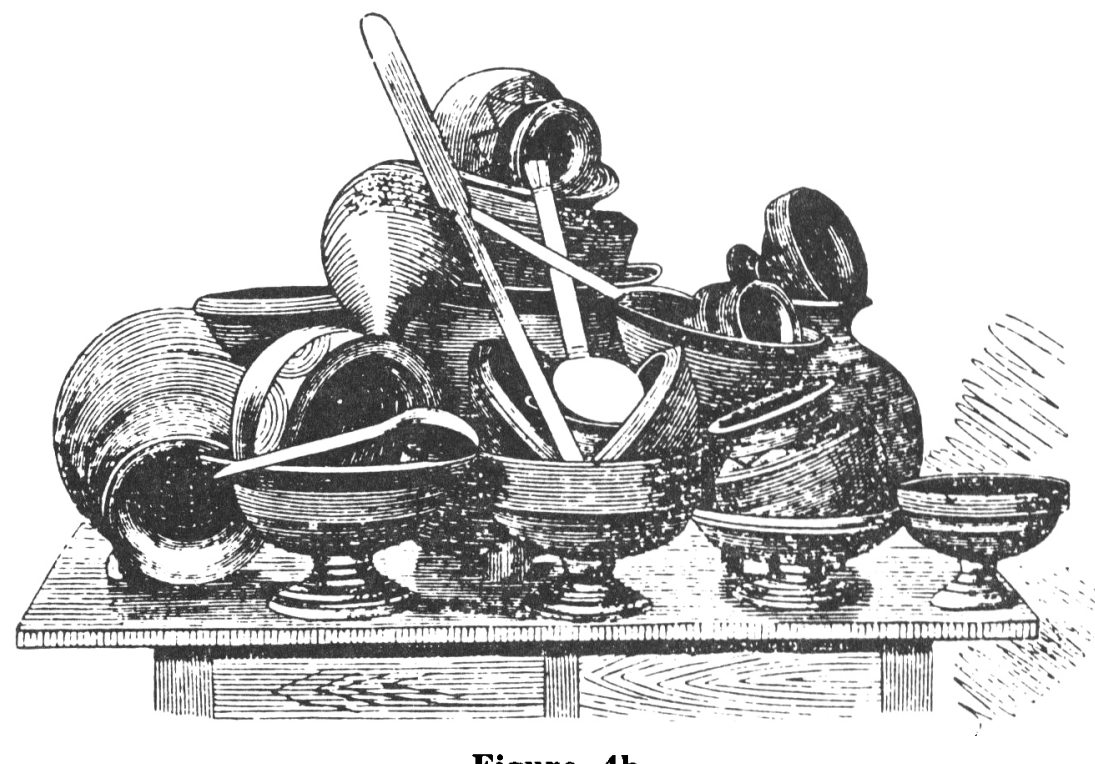

Figure $4 \mathbf{b}$

The engraving based on Figure 4a, and printed in $M B$ 1884, 138-40. The exactness of the reproduction is impressive, but the engraver has repaired the table just a little. 
To argue that a missionary photographer in West Africa was finding his camera leading him to a fresh and positive look at his cultural environment in the late $1860 \mathrm{~s}$ is to swim against all the currents of recent historiography. And to base this on the existence of only three of the images offered for sale in May 1868 would hardly be convincing. But the argument that Hornberger, at the end of his period as a photographer, was coming to a more positive and appreciative approach to indigenous culture in the images which have survived from these years has three parts: the actual number of surviving images which one can read in this way, their use in the 1880s, and the logic of Hornberger's position as photographer after the collapse of the sponsoring scheme.

There are in fact seven images from the last phase of Hornberger's work as photographer which are concerned with depicting indigenous culture, and not three. Two sets of three images each may well have been intended to be seen as series: spinning, weaving, and two men wearing indigenous cloth; grinding corn, stamping fufu and a family eating. The seventh image shows local pottery composed into a "still life." 34 Seven images is still not a large number, of course, but in view of the known laboriousness of the process Hornberger was using, and the way these images are very different from the images of indigenous life issued in 1864, it is fair to regard them as a group which documents a conscious change in the themes he was photographing rather than being the products of whim or coincidence.

These images, plus another "still life" showing yams and cassavas, are used to make a series of surprisingly positive comments on traditional culture in the pages of $M B$ between 1884 and $1888 .{ }^{35}$ Repeatedly in these essays it is urged that Africans know how to work, and do so to some purpose in their own culture, producing pottery, cloth, iron tools, and their daily food. ${ }^{36} \mathrm{It}$ is clear that these texts were being used partly to carry on a dialectic with the new harsher colonialism connected in Germany with the acquisition of German colonies in the mid-1880s (Gründer 1982; Ustorf 1989:31-50), as, for example, in this extract from a commentary on an engraving showing a woman grinding corn $(M B$ 1888:47):

Since we obtained colonies people have acted, in our Fatherland, as if Africa represents an exception to the general rule that if you want to eat, you have to work. Prizes have been offered for the best suggestions about how to train the African to work, and many people have responded, both those who might have something useful to say, and those who do not. It is a very curious mistake when people think that the African does not know how to work and has to be taught this. But the oddness is explained when you realise that the gentlemen involved do not actually mean that the African has to learn to work, but to learn to work more. And they do not mean that he will eat the extra "bread" he produces himself. They are the ones who plan to eat the extra bread that the African has produced by working more. That is the explanation of [what looks at first like] a curious mistake.

This, perhaps unexpectedly fierce, anti-colonial accent must be balanced 
against a colonialism in the mind of the writers of the commentaries (both in the editorial matter and texts written by named missionaries). The assertion that Africans know how to work is usually buttressed by the observation that it is part of the divine definition of the human race that people must work if they want to eat, which makes this a statement of theological principle as well as of an anti-colonial anthropology. In addition there is no doubt in the minds of the writers that in the hierarchy of civilizations Ewe culture lies far below that of the German-speaking peoples, though not actually at the very bottom of the heap. In other words the commentators feel free to apply two absolute extraneous scales of value to Ewe culture-a central feature of a colonial relationship.

Yet it is clear that this kind of colonialism could take a positive stance on aspects of traditional culture-indeed that it was potentially open-ended as far as appreciating and cooperating with indigenous culture was concerned. There was here a conflict about the orientation and values of German colonialism, which is the context in which these essays have to be understood. On the one hand a plantation capitalism saw African populations as a source of cheap, undemanding, and expendable labor at its disposal. On the other a mercantile capitalism linked to the North German Mission potentially, and in many ways in practice as well, saw African populations as partners in trade, and expected that they would develop the initiative to seize commercial opportunities which came their way (Gründer 1982 and Ustorf 1989).

Can the commentaries from the 1880 s, with their surprisingly positive outlook on traditional culture, be read back into the 1860 s and be understood as documenting the process of thought which led to these photographs being taken? We have already pointed to the striking continuity in the leadership of the North German Mission between the 1860s and the 1880s, which argues for these images having been seen and understood in terms of the appreciation of indigenous culture when they were first sent to Bremen. The only actual indication of a link to Hornberger as photographer comes in the discussion of the image of the woman grinding corn, where there is a brief statement of the probability that she had dressed in her best when she realized she was to be photographed. These few words are suggestive, for they indicate a certain quality in her relations with Hornberger. They imply he had to negotiate about the picture and was quite prepared to come to an agreement which meant the image would project an image of enhanced dignity. It suggests that the leadership in Bremen were aware of this, which would not be too surprising considering that they were the people who had urged Hornberger to take photographs, who read his reports, debriefed him when he arrived in Bremen on furlough, and transformed his material into publications for the Mission's supporters.

A final argument for urging that Hornberger had found a new visual approach to the world around him in these photographs is basically an attempt to assess the impact of the abandonment of the sponsorship scheme on Homberger as a photographer.

Photography as practiced by Hornberger was an onerous activity. ${ }^{37} \mathrm{We}$ know that Hornberger expressed considerable unhappiness when he learned that 


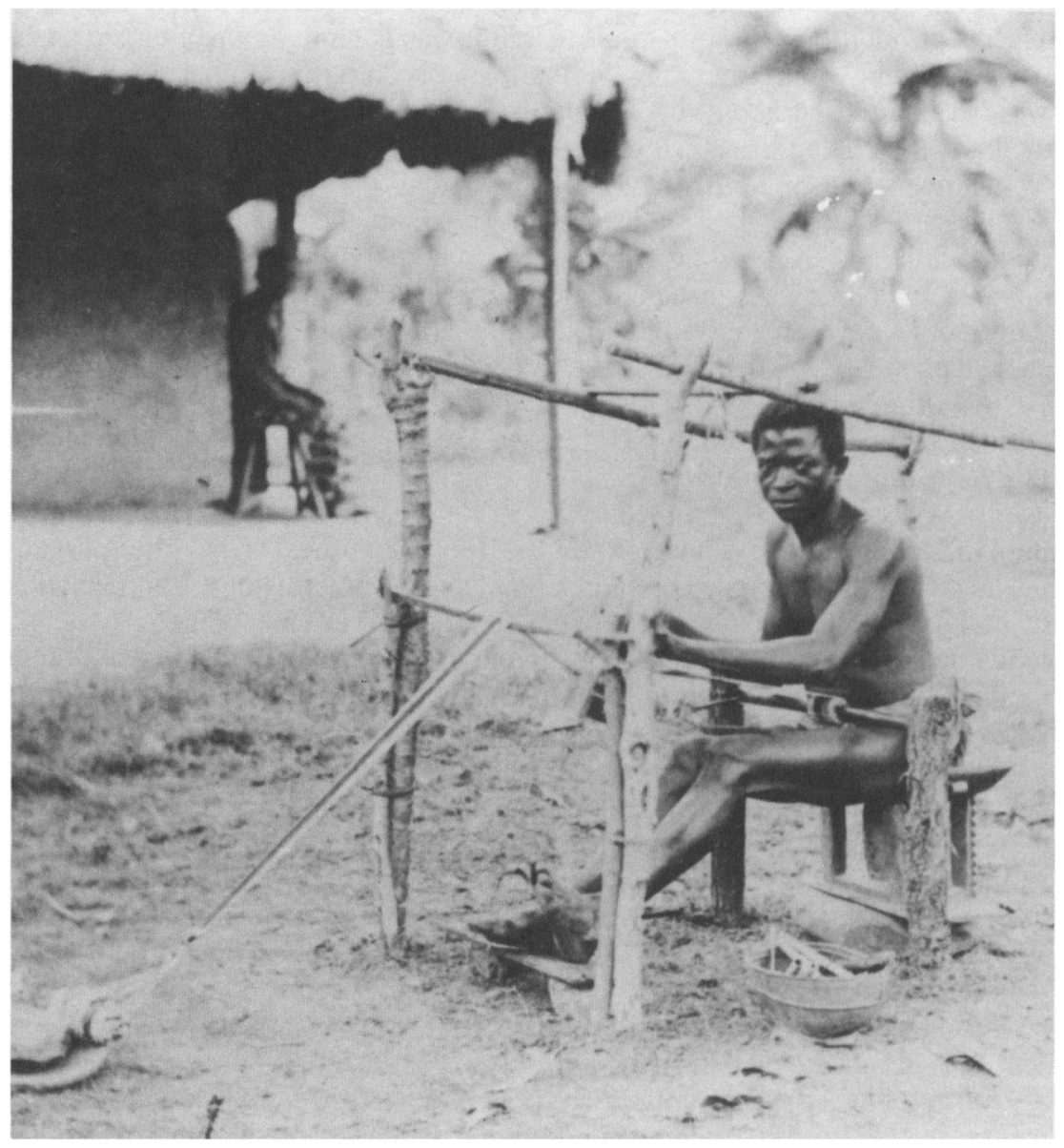

\section{Figure 5a}

Basel Mission Archiv QD-30.01456. An Ewe weaver, an image belonging to the final phase of Hornberger's photography (thought this cannot be finally documented). 


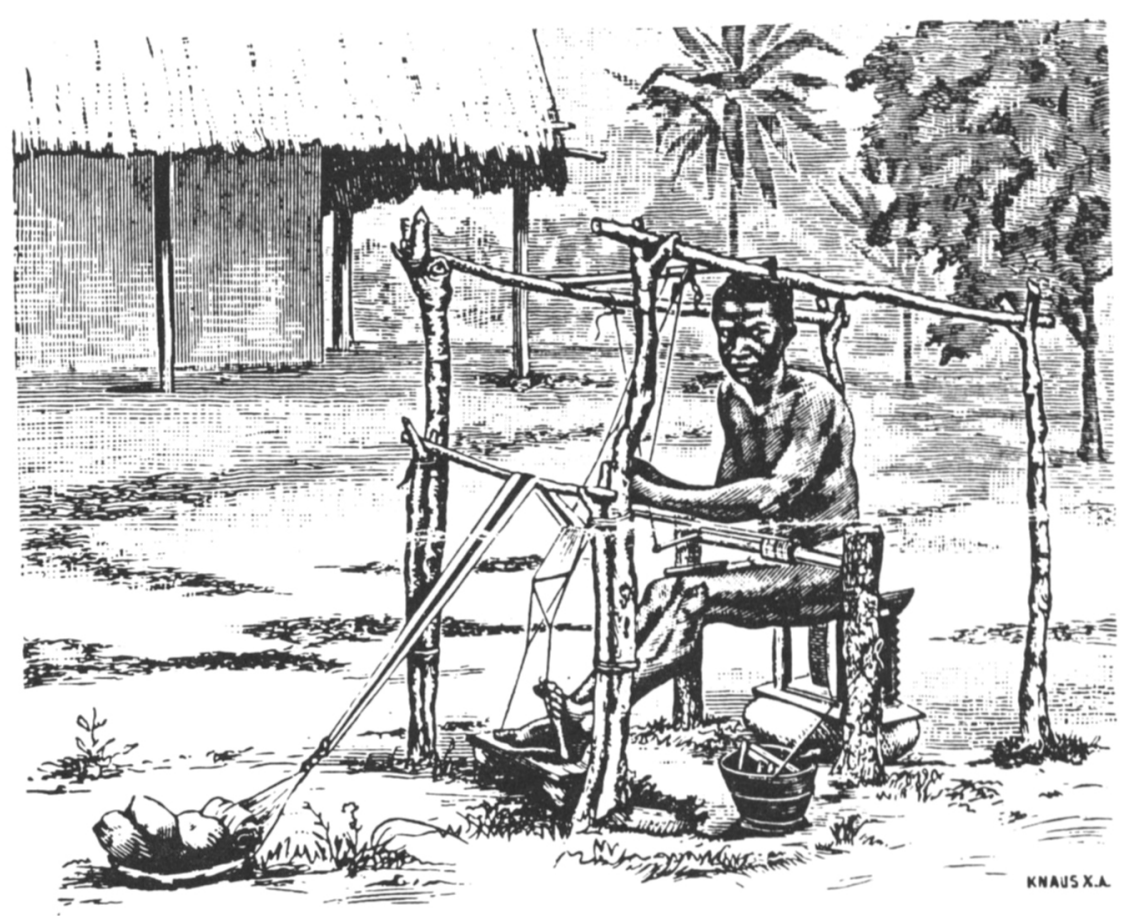

\section{Figure 5b}

An engraving based on Figure $5 \mathrm{a}$, and printed in $M B$ 1885, 108-10. With this image one could almost talk about the engraver's enhancement of the picture. Much is sharply drawn, which on the vintage print is out of focus or vague through lack of contrast. Did the engraver have a better print to work from? The only substantial changes are the omission of the figure on the verandah, and the different shape of the pot on the weaver's left. But the acid test of accuracy would be, of course, if this version of the image could persuade an Ewe weaver that the engraver had drawn the loom carefully and accurately from life. 
he was to be expected to take photographs-in his experience photography demanded time and resources better invested in other activities. Once known as a photographer, however, there were compensations for him-he was acknowledged as a pioneer and evidently not above seeking additional profile through his photography, e.g., as we have seen, through getting his images brought to the attention of the Queen of Württemberg. From the moment the sponsorship scheme was wound down, however, it was clear that much of his early photography had become more or less valueless from the point of view of the Mission's public relations.

The possibilities at his disposal seem evident. He could throw in the towel, he could try to build up a broader photographic record of the work of the mission, or he could direct his camera outwards to the surrounding society. He seems to have attempted the latter, at least for a time. What is striking is that he apparently did not seek dramatic and alien images to continue the negative train of thought about indigenous culture which had led to the sponsored purchase of slave children. Instead his new images stress the dignity of people going about their daily occasions and their skilled and purposive activity.

There seems, therefore, good reason to identify a change in Hormberger's photography between 1863 and 1868 . His camera pans, away, as it were, from the small huddle of those who were thought to be reproducing in West Africa village life as it was practiced by the pious in Protestant German-speaking Europe. It focuses instead on people living in their traditional way outside or on the edge of the mission stations. ${ }^{38}$ And if one is correct to identify this change, its drama should not be underestimated. When Hornberger started photographing, his images were consciously put into the service of a simplified and self-serving Bremen Mission "construction" of African culture and its evils. His last images, on the other hand, could be put to use later in the Mission's critique of another, new and simplified colonial "construction" of African culture, self-serving in the way it justified a thoroughgoing mise en train of German economic interests in German colonies.

None of the information is available necessary to investigate whether the changing orientation of Hornberger's camera was a result of instructions from Bremen or of a train of thought which developed at first in Hornberger's own mind and contacts in West Africa. Much of the recent literature on the nineteenth-century Bremen and Basel Missions would tend to suggest that the change was determined by the leadership in Bremen. Jon Miller has documented how thoroughly the Basel Mission was organized to carry the will of the Basel Committee abroad, despite the obvious difficulties which resulted from slow postal services and the fact that very few members of the Committee had set foot south of the Mediterranean (Miller 1990, 1991). Werner Ustorf's full-length study of F.M. Zahn's Inspectorate of the North German Mission stresses the intellectual capacities which Zahn brought to his 


\section{G $\tilde{A}$ \\ K A N E M O - W O L O. READING BOOK \\ IN THE Gĩ OR AKRA LANGUAGE, FOR THE VERNACULAR SCHOOLS}

IN THE AKRA AND ADANGME COUNTRIES, GOLD COAST.

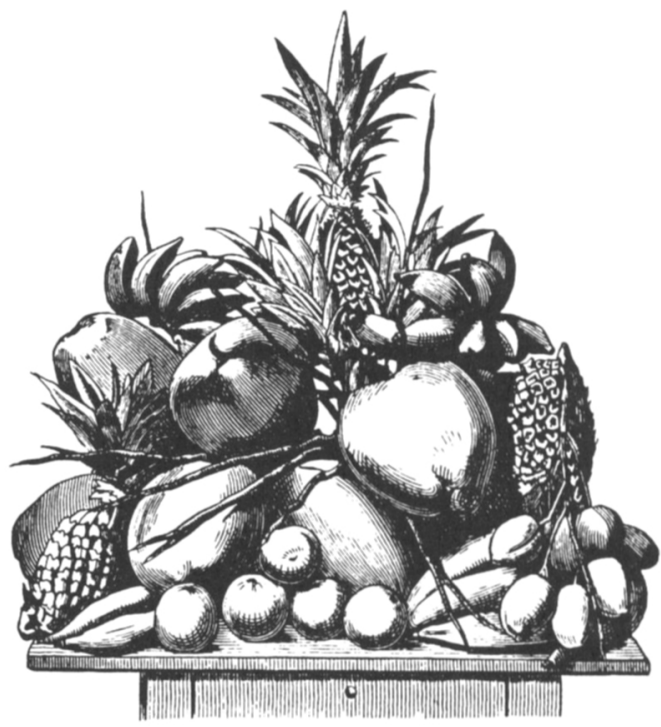

BASEI, 1883.

PRINTEI) FOIR 'TIIE WVANGLLICAL MISSIONARY SOCIF,TY.

Solp at the Baser. Mission Book lepository, Christiansbono, Gold const, W. Afica.

\section{Figure 6}

Engraving of a Hornberger image-still-life-with-fruit-on the title page of Ga Kanemo-Wolo, a Ga reading book published by the Basel Mission in 1883. The original photograph is at QD30.014.QD-30.014,51. The dimensions of nineteenth-century acculturation, since largely forgotten in temperate latitudes, become apparent. The texts offered for reading in this book are mostly written by indigenous teachers and include materials about Africa and many Anansesem stories. The engraving reproduces a photograph taken not a hundred miles away from where even the most distant pupils who used the book were living. 
work, and the characteristic claim he made, with the Bremen Committee at his back, to control and regulate his missionaries' overseas work in detail (Ustorf 1989).

Both authors have to acknowledge, however, that such detailed control was not always possible. Miller identifies figures who did not conform to the system laid down in Basel, but turn out to have helped give the Basel Mission in Ghana new orientations which it needed (Miller 1991). Ustorf offers insights into a situation where Zahn expected too much from his subordinates, and tried to do too much himself, being frequently in arrears with his letters, capable of penning 30-page missives on topics he found most important and then complaining that his field staff did not seem to have been reading what they had been sent (Ustorf 1989:80, 106, 108).

There is certainly room for arguing that even in tightly-organized Teutonic institutions like these two missions there was room for someone like Hornberger to develop the kind of initiative which would explain the change in the character of his photography. This would especially be so in a situation of confusion and difficulty as the Mission found itself forced to abandon what had been for several years visibly the central plank of its work.

There is, however, another important train of thought which would lead one to see the crucial Denkarbeit which led to these last images on the side of Hornberger, rather than Zahn or Vietor: the history of what David Arnold has called the "interactive aspects" of relations between missionary societies and non-European cultures. ${ }^{39}$ To understand the full force of this argument we need to recall the modern anthropological literature on the Presbyterian Church congregation in Akropong, the Ghanaian town which the Basel Mission made its capital for many decades (Middleton 1983, Pobee 1986, Gilbert 1988). This indicates that, far from indigenous culture having been destroyed by a long and intensive missionary presence it continues to stamp much of what goes on in and around the church, both organizationally and intellectually. The 150 years of Christianity in Akropong are a history of an interaction between Church and indigenous culture in which both have changed, and not necessarily in the way foreseen by the missionaries. The same can almost certainly be said about the historic centers of North German Mission presence among the Ewe. ${ }^{40}$

The episode which we have been considering in this paper is part of that interactive history. The collapse of the scheme for the sponsored liberation of slave children must count as a very striking example of the strength of conscious or unconscious cultural resistance in the face of mission work, and the inability of a missionary society to push through a policy based on a false reading of the social 'facts' of its environment. The refusal on the part of the majority of the children to become what the Europeans wanted them to be may have seemed inchoate and incomprehensible to the missionaries. Even so, it shows how even children and young people whose experience of indigenous society had, presumably often, not been very satisfactory, still lived by patterns of thought and emotion which made them seek relations and experiences other than those the missionaries had to offer. 
The interactive history includes the missionaries, of course, even if their changes in response to indigenous life in the nineteenth century were pragmatic, unofficial, and always liable to be reversed by a surge of moral orthodoxy directed from 'home.' But changes there must have been, in the search for a basis which allowed them to enter into the kind of relations with indigenous people which the latter could understand and wish to take up themselves. We have scarcely begun work on the history of the pragmatic compromises with indigenous culture which the missionaries had to work out over the many decades of Basel and Bremen mission presence in southern Ghana. Almost certainly one of the first things they had to do was learn to live with the ties which linked most indigenous people, unless of stranger origin, with the extended family, and one of the signs we need to search for when looking for indications of these pragmatic compromises is the maintenance of ties to the extended family among Christians. ${ }^{41}$

Another compromise will have been the missionaries' realization that future economic activity did not necessarily lie with the adoption of Europeanstyle products, organization and technology. This is where Hornberger's last photographs may well fit in, documenting the process by which he and his colleagues turned from seeing their future as being linked to ex-slave children becoming adults and working within the framework of the church, its schools, and European-style handwork and farming, to realizing that indigenous culture had its own economic profile and dynamic with important functions for the present and interesting possibilities for the future.

This assertion is admittedly speculative, but the North German Mission's general view of its environment must have had a very polarizing effect on relations between missionaries and indigenous people. Hornberger will have been given furiously to think by the failure of the scheme which had given his photography its main function. And the process of deciding what photographs to take in the new situation, composing the image wanted, getting negatives prepared and exposed, and then assessing the image captured would have been a catalyst in helping him to a new vision of what indigenous society could signify.

\section{VI}

If this is what happened, however, the medium- and long-term impact of this change on the North German Mission was by no means profound. In the 1880 s its Directorate may have advocated the possibilities of indigenous development in the economic sphere, but Ustorf's study of Zahn (Ustorf 1989) is a long and eloquent statement of the way openness to indigenous development in the cultural and religious sphere was not part of his worldview. And at the level of the Mission's supporters? It seems that with the suspension of the sponsoring scheme the momentum went out of Hornberger's photography. The earnings from photography in the North German Mission's published Annual Accounts for 1867 and 1868 tell an eloquent story, declining as they do by $80 \%$ from one year to the next, although new photographs were offered 
for sale in $1868 . .^{42}$ And it is hard not to feel that, in spite of war and his frequent illnesses Hornberger would have found his way back to photography if there had been a strong demand for his product. ${ }^{43}$

Surely not for the last time in the history of mission, a parallelogram of forces seems to have built up around work in the media which helped determine its use and its content. In the argument of this paper, Hornberger came to experience photography's value as an instrument which helped him to explore the cultural world around him. But the Mission's supporters had their own agenda. Frustrated in their wish to see the world in Africa in their own terms, and to force reality, in the form of individual biographies, into the shape these terms implied, they lost interest in pictorial images. Faces without names could not hold their attention, and lives which did not correspond to their view of what ought to be happening did not have the same power to arrest attention.

It would be a pity if analyses of missionary photography concern themselves only with photographs as propaganda. But however much care we invest in locating cases where photography turns out to have helped to explore, experience and uncover new possibilities of relationship, its propaganda function cannot be left to one side. And so long as Europe and North America remain central in media and economic terms against the African periphery, the danger remains very great that the demands of propaganda, reflecting as they do the preconceptions of a European or North American public, will determine the images of Africa in circulation.

The critical self-consciousness of missionary movements should, after almost two centuries of intensive contact with African cultures, resist this narcissistic tendency and strengthen the search for that intercultural encounter we can sometimes glimpse even in the nineteenth-century history of a German-speaking Protestant mission, even if only, as here, seven shutteropenings long, in the photographic experience of Christian Hornberger.

\section{Notes}

* I would like to dedicate this essay to the memory of Hans Ott, a Swiss protestant pastor who died in 1991 at the age of 49 . For almost 20 years he was the General Secretary of one of the two major Swiss protestant development aid organizations, Brot für Brüder/Brot für Alle. He was committed to working for a new international economic order in which the efforts of traditional rural populations and the poor in the towns to keep body and soul together would add up to a viable economic basis for their lives. In this capacity he helped to bring about some important changes in language and action in Swiss public life in relation to the Third World. He also recognized very early on the potential importance of the photographic collection in the Basel Mission Archive, not least to present-day discussions about development and international mutual responsibility. The scope of our current work on this collection, both technical and historical, owes a lot to his interest.

1. This essay reflects a very happy period of cooperation in and around the Basel Mission Archive, as a number of us worked to identify the scope and significance of our holdings of early photographs. Above all I would like to thank Timothy Garrard, who gave some key pieces of advice about working on early Ghana photographs in the Basel Mission Archive, and who put his knowledge of our collection unstintingly at the disposal of this paper. Christraud Geary made the suggestion that we should try to approach the analysis of holdings of old pho- 
tographs about Africa through a consideration of the professional activities of these (amateur!) photographers, and has always encouraged the work we do in Basel on our photographic holdings. My colleagues in the team currently carrying through the Photo Project in our ArchiveBarbara Frey Näf, Claudia Fritz, Regula Iselin, and Anna Pytlik - have offered acerbic and very professional critiques of various drafts of this essay. Adam Jones read an early version and made some valuable suggestions. Rosemary Seton, Rosemary Keen, Jean Woods, and the staff of the Bremen Staatsarchiv were very patient with the kind of unorthodox questions archivists get asked by people doing research on photographs.

The paper was presented first, in German, at the Kolonialgeschichtliches Symposium in Berlin in August 1991, and then at the African Studies Association meeting in St. Louis in November 1991. Since then jts contents have been presented in part, in various forms, at the Second International Conference on Visual Anthropology in Amsterdam in June 1992, the Workshop on Mission Archives at SOAS in July 1992, and the Conference "From Christendom to World Christianity 1492...to 1992" organized jointly by Yale Divinity School and the Centre for the Study of Christianity in the non-western World, New College Edinburgh, in September 1992. For a preliminary version see Jenkins (1992).

2. An archival reference number has since been assigned to this album-QC-30.016. Richter took a camera to India in 1854 or 1855 -(Annual) Report 1855, 12.

3. Archival reference number QD-30.011, image no. 60.

4. This particular image, a group portrait of an Asante embassy to the Governor in Cape Coast, has since become very familiar. The engraving based on the daguerreotype graces the dust jacket of Wilks 1975. Its provenance and detailed content is mentioned in ibid. 466:n218, though perhaps not with the emphasis and fanfare this image deserves. The original daguerreotypes cannot be traced.

5. It is virtually certain that these images, primarily views of buildings and places in southeastern Ghana, did not originate with West. Is this early evidence for the work of a professional photographer on the Ghanaian coast?

6. This album, QD-30.011, is mainly a collection of the work of W. Locher, though his successor as Basel Mission photographer, T.G. Breitenbach, who took very few photographs, is also represented, as is a Ghanaian photographer called Fred Grant, whose images here (of Cape Coast) date from ca. 1874. The album also includes a few views of the Anum station of the Basel Mission taken by Hornberger in 1869, just before the Asante army captured Anum and sacked the Mission's buildings there (see also note 22 below).

7. For technical questions in relation to his photography see Hornberger's letters to the Inspector of the North German Mission dd 29 October 1863, 1 December 1864, and 25 April 1865. The letter of 29 October 1863 also mentions the contact with Locher. See Archive of the North German Mission in the Staatsarchiv Bremen, Depot 7/1025, ref. nos. 9/6, 9/7, and 10/1.

8. West was no missionary but, as the title of his biography (West 1857) suggests, a pastor from Britain on deputation to the Methodist congregations in West Africa. A cursory look at Methodist Mission publications in the third quarter of the nineteenth century showed no particular interest in photography in this period.

9. Virtually all Bremen missionaries in the nineteenth century had been trained at the seminary in Basel. Many of them, like Hornberger, came, themselves, not from north Germany, but from the south, from Württemberg, where the bulk of the Basel missionaries had grown up. A number of Bremen missionaries were even related to Basel missionaries in Ghana. And before the North German Mission built its own "hill station" in Amedwofe, Bremen missionaries used to recuperate from illness on the Basel "hill stations" in Aburi and Akropong.

10. Hornberger's letter to the Inspector of the North German Mission dated 2 June 1863 (Bremen Staatsarchiv 7/1025 ref. no. 9/6) protests gently about the camera which he has heard is on its way to him; he knows, from his experience during training in the Mission House Basel, that photography is expensive and can waste a lot of time. A letter from the Basel Mission printer in India in 1861 asks that a photographer be sent to India-"a good photographer, not merely one who has learned photography on the side during his time in the Mission Seminary in Basel"--Jakob Hunziker to the Inspector of the Basel Mission, dd Mangalore 2 August 1861, Basel Mission Archive C-1.28,36, transcribed in Jakob Hunziker aus Wynau in Kanton Bem (1987), Part 7. Although I have as yet found no direct reports in the main Archive series on the Basel Mission House and its Seminary as to photography being an optional extra on the curricu- 
lum for would-be missionaries in the 1850 s, it seems unlikely that, in a patriarchal organization like the nineteenth-century Basel Mission, young men in training could learn photography without the express encouragement and support of the Basel Mission leadership.

11. A study of images and the use of photography in the Church Missionary Society could be very rewarding. From 1850 the Church Missionary Gleaner published images frequently, often with a detailed title or explanatory notes and at least a hint about their provenance. In addition, the CMS Archive in the Society's London Headquarters still (August 1991) holds the "Missionary Leaves Association Photo Book" (ref. no. H/H31/AG1/1). Its earliest African photographs seem to date back to $c a .1870$.

12. For Deimler's training in photography in Stuttgart see his account of his journey to Bombay in 1854/55, Basel Mission Archive C-10.42,9. I would like to express my delighted thanks to Deimler's granddaughter, Ruth Weygoldt-Deimler of Lörrach, who has given a typed copy of this document to our Archive. The original has been in family hands, and seems to have been lost during World War II. I would also like to express my thanks to Jocelyne Murray, who drew my attention to the reference to Charles New's photography.

13. The Basel Mission Archive contains a "Cliché-Buch," a sample book of about 1,400 images, mostly engravings, from which authors and editors apparently chose the illustrations for their publications: Archive Ref. no. QQ-30.001. Its latest images appear to date from the 1890s. There are about 100 images on the "Gold Coast" pages, about a quarter of which I can already identify as having been drawn from photographs, including photographs taken by Locher and Hornberger. A systematic investigation of the images' origins would, of course, increase this proportion, and Timothy Garrard estimates the number of engravings based on photographs as somewhat higher than my 25\%. The Calwer Missionsverlag seems to have published its sample book in 1883. The 1883 volume was republished in 1987 (see Calwer Verlagsverein Bildertafeln, 1883/1987).

14. My colleague Barbara Frey Näf, who is leading the current project to catalog the Basel Mission photographic archive, warns me that I should use the rather cumbersome term "wood engraving" to describe the process leading to the production of these pictures, see Gascoigne 1986:6a-e. I have, however, continued to use the more general term "engraving" because the images in West's book seem to have been lithographed (Wilks 1975:218n 466) and it was certainly a subject of discussion in the Basel Mission whether the early photographs brought back from Ghana should not be engraved on steel for reproduction (Basel Mission Komitee-Protokoll 28. July 1857 ). Just what processes were used to publish which images is obviously a matter needing investigation.

15. For an engraved version of this image see, for example, $M B$ 1888:67-70. A vintage print of the original is at QD-30.014,58.

16. These were Missionary Papers for the use of the Weekly and Monthly Contributors to the Church Missionary Society (London, from 1816), Nachrichten aus der Heidenwelt (Stuttgart, from 1823), Papers Relative to the Wesleyan Missions and to the State of Heathen Countries (London, from 1820), and Missionary Sketches, from 1820.

17. The Church Missionary Gleaner is often quite specific about the artists who provided sketches from Nigeria as the basis for engravings-e.g., Mrs Hinderer supplied the sketch of the new church in lbadan which was printed as an engraving in the Gleaner for January 1856.

18. The commentary in $M B$ to a picture of a woman grinding flour is that she had no doubt dressed herself in her best to be photographed. (MB 1888:47-48, original QD-30.014,57).

19. For Hornberger see $M B$ November 1884:169 and note 27 below. Locher's camera was handed over to his colleague Breitenbach in 1867, but Breitenbach left Ghana soon after, and we have not yet been able to trace any indication of who his successor as photographer may have been.

20. For the areas of "first contact" in sub-Saharan Africa from ca. 1850 see the sketch maps of the regions for which European sources are available in the periods 1820-1840 and 1840-1880 in Jones 1987:22-26.

21. The North German Mission is the subject of a considerable modern bibliography, though in these works photography has never been treated as more than a marginal matter, if mentioned at all: Debrunner 1965; Schöck-Quinteros and Lenz 1986; Ustorf 1986; Pabst 1988; Ustorf 1989.

22. The archival holdings of the North German Mission are held by the Bremen 
Staatsarchiv. A considerable number of photographs, including vintage prints of some Hornberger images, remain in the hands of the Mission headquarters, however. The main location of Hornberger vintage prints in Basel is the album QD-30.014, though some other images are to be found scattered through the D-30 series. Hornberger's photographs of the Anum station of the Basel Mission, before it was sacked by an Asante army in 1869, are pasted into the album QD-30.011, which is the main repository of Locher's photographs. Hornberger also took a family portrait of the Ramseyers in Anum in 1869 (QS-30.003.0417.07). It appears that he was requested by the Basel Mission to take these photographs because the Basel Mission photographers had been unable to visit Anum.

23. Hornberger to the Inspector in Bremen (from Oeschelbron in Wurttemberg) 3. April 1866, Staatsarchiv Bremen 7/1025, 4/67.

24. "Herzog" as the surname of his adviser occurs repeatedly in Hornberger's letters to the Bremen Mission Inspector. The staff of the Bremen Staatsarchiv suggest that it must have been Johannes Carl Herzog, who ran a "Workshop for Daguerreotypes and Photographs" in Bremen in the 1860 s.

25. This rather drastic judgement, based, admittedly, on a short visit to Bremen, seems to be confirmed by Werner Ustorf; see Ustorf 1989:7n11, 320-22.

26. See $M B$ 1863:632, 640,665-66, and 672; $M B$ 1864:724; for information on the beginnings of Bremen Mission photography in West Africa. For an indication that Bremen Mission supporters could ask for photographs to be taken-or rather, order portraits of specific people-see $M B$ 1865:758.

27. The final reference to photography at the beginning of this period comes in the Bremen Mission's published Annual Accounts for 1869, bound with the Basel copy of the $M B$ for August 1870:1070. This records that the Mission had enjoyed an income of $f 8 / 3 / 4$ from the sale of photos in West Africa. The first reference to photography in the 1880 s comes in the report of Hornberger's death in 1881 ( $M B$ 1881:153) in which it is said that the ruler of Ho and the traditional priest had come to the Mission Station to offer condolences. The missionary with whom they were speaking had reminded them that through Hornberger's photography their faces were known to the Bremen Mission's elders at home.

28. Ustorf 1986 and 1989 provide considerable biographical material on these two men.

29. $M B$ 1888:27-30, original QD-30.014,59. That the family are shown not sitting at a table, and divided into male and female groups, had of course its special message in the context of a Mission which insisted that a Christian family eat together. Rural viewers of such images in Europe, however, may well have been reminded more of their own informal eating habits alfresco than of the Mission's ethical message. 216.

30. This phase of North German Mission work is treated critically in Ustorf 1986:192-

31. "Petrus Neuenkirchen:" children were sometimes named after the place where the Mission's supporters lived who had put up the money used for their purchase.

32. Christian Aliwodsi was the subject of an essay in $M B$ 1884:52-64, which included a family portrait published as engraving.

33. See the report on the impact of the Slave Emancipation Ordinance of December in the Gold Coast Colony ( $M B$ May 1875:1365-66), and a note on former freed slaves living in Keta in $M B$ March 1880:44.

34. The images of textile production are women spinning (MB 1885:6-8, original QD30.014,55); a weaver (see Figures 5a and 5b); and two men wearing indigenous cloth (probably $M B$ 1888:80-84, original QD-30.014,60). The images of domestic life are grinding corn (see note 18); pounding fufu (see note 15); and a family eating (see note 29). For the "still life" with indigenous pottery see figures $4 \mathrm{a}$ and $4 \mathrm{~b}$.

35. $M B$ 1884:98-106. I have not yet seen a photographic original of this rather strange engraving.

36. There is even a note of warning in the essay about the weaver (see figures $5 \mathrm{a}$ and $5 b)$ on the varieties of African culture. Readers have to be clear that these essays refer to the Ewe people. Europeans generalize all too uncritically about Africa: "A European only has to see a little bit of Africa-and that superficially-and he starts saying 'Africans do this, or that.....' It would be a more modest and more correct way of speaking if they were to say 'the black people I have seen do this or that."' (MB 1885: 108-09). 
37. The adjective "onerous" occurs repeatedly in this essay, as applied to the photographic technique Hornberger used, but it is not inappropriate. If he were using the wet-plate collodium process, it meant something like 20 steps between beginning to prepare a glass plate for photography and the final fixing of a negative. Making a print from the negative involved further careful chemical manipulations.

38. The possibility arises that some of these photographs were actually taken of Christians, indeed the group eating and the two "workers" in their cloths are stated to be Christians (see note 34). This does not weaken the argument that these images indicate a greater openness to indigenous culture, however: Figure 2 is by no means the only early Hornberger photograph which points to the wholesale uncritical takeover of European rural patterns of life and rural technology on the Bremen Mission Stations.

39. In his introduction to the Workshop on Mission Archives held in SOAS in July 1992.

40. Brigitte Maier, a research student of the Department of Anthropology at the University of Amsterdam, is working on the influence of traditional thought patterns on Christian belief in Peki, a town southwest of Ho, which has a similarly long history of contact with the North German Mission.

41. One such sign crops up in the explanatory essay about the Aliwodsi family (see note 32). In 1883 Mrs Aliwodsi, Christian and catechist's wife, was ill for a long time. In a letter to one of the missionary wives, at that time in Europe, quoted in this essay, her husband wrote: "In the end her grandmother Nyamacro in Vodza wanted her to stay with her....she came three times to fetch her. I would not let her leave. But when my wife herself asked me to allow her to go, I had her carried there. It was only in Vodza that the illness could be identified ("gab sich zu erkennen"), and immediately she started recovering, though she was still very thin and weak and it will take a long time before she has recovered fully." Assuming that Nyamacro was no Christian (and there is no reason, looking at the essay as a whole, to believe that she was), this is a very suggestive story about family ties continuing to function across the boundaries between "Christians" (even leading Christians) and "non-Christians" created by the missionaries.

42. Income from photographs dropped from 155.52 Bremer Thaler in 1867 to 28.66 Bremer Thaler in 1868 (MB 1868:944 (Annual Accounts for 1867) and MB 1869:1002 (Annual Accounts for 1868). The separate German currencies were unified on the basis of the German Mark only in 1871 .

43. The inland stations of the North German Mission had to be evacuated and were later sacked in the course of the Asante War which broke out in 1869. I have seen no reference to the loss of the camera Hornberger had been using. Hornberger was frequently ill in the 1870s. One situation, in 1874, in which he was able to cancel a planned journey back to Europe for recuperation, is worth mentioning in detail, since it includes another figure of interest to Africanists, C.C. Reindorf. Hornberger had been suffering from diarrhea and had traveled to the Basel Mission hill stations in Akwapim to recuperate. Reindorf tried to treat him, but the medicine he first prescribed was not successful and at this stage Hornberger wrote to Bremen telling them on which ship he was planning to return to Europe. Reindorf tried a second and different course of treatment, which succeeded. It is clear that both were traditional herbal recipes (though they are not described here with botanical accuracy). Hornberger remarks that, unlike in the Ewe area he knew, where such knowledge was tightly restricted by the traditional priests, in Accra anyone could purchase recipes from traditional healers and use them,. When he offered to buy this secret from Reindorf, the latter asked for a price Hornberger could not pay without consulting the authorities in Bremen-f20. ("Neger-Doctoren," $M B$ September 1874:1313-14).

\section{Bibliography}

Calwer Missionsblatt (first issued 1828).

Calwer Verlagsverein 1883/1987: Bilder-Tafeln zur Länder und Völkerkunde, Calw \& Stuttgart, 178 folio pages. (the 1987 reprint may be cataloged under a variant title: Calwer Historisches Bilderbuch der Welt, ISBN 3-7668-0816-8).

Christaller, J.G. Ga Kanemo-Wolo. Reading Book in the Ga or Akra Language. Basel. 
Church Missionary Gleaner, London, from 1850.

Corbey, Raymond, 1990: "Der Missionar, die Heiden und das Photo. Eine methodologische Anmerkung zur Interpretation von Missionsphotographien" in Zeitschrift fur Kulturaustausch 40: 460-65.

Debrunner, Hans, 1965: A Church Between Colonial Powers: A Study of the Church in Togo. Accra.

Frey Näf, Barbara 1990: "Der Dornröschenschlaf ist zu Ende. Erschliessung von Photoarchiven mit Hilfe der Elektronischen Datenverarbeitung (EDV)-das Beispiel der Bildersammlung der Basler Mission" Zeitschrift für Kulturaustausch 40:553-60.

Gascoigne, Bamber 1986: How to Identify Prints, London.

Geary, Christraud 1988: Images from Bamum. German Colonial Photography at the Court of King Njoya, Washington D.C.

Geary, Christraud 1990: "Impressions of the African Past: Interpreting Ethnographic Photographs from Cameroon." Visual Anthropology 3:289-315.

Gilbert, Michelle, 1988: "The Sudden Death of a Millionaire: Conversion and Consensus in a Ghanaian Kingdom." Africa 58:291-313.

Gründer, Horst, 1982: Christliche Mission und deutscher Imperialismus. Paderborn.

Jakob Hunziker aus Wynau in Kanton Ben-Buchdrucker der Basler Mission in Südindien, 1857-63 (1987); Basel.

Jenkins, Paul, 1992: "Die erste Generation der Missionsphotographen in Westafrika und die Wahrnehmung einheimischer Kultur. Ueberlegungen zu Beständen in Archiv und Bibliothek der Basler Mission" in Rassendiskriminierung, Kolonialpolitik und ethnisch-nationale Identitat. Münster, 510-523.

Jenkins, Paul, and Christraud, Geary 1985: "Photographs From Africa in the Basel Mission Archive." African Arts 19:56-63.

Jones, Adam 1987: "The Dark Continent: a Preliminary Study of the Geographical Coverage in European Sources, 1400-1880." Paideuma 33:18-28.

Josenhans, Joseph, n.d. [but from the early 1850s]: Bilder aus der Missionswelt fur die deutsche Jugend nach englischen Originalien. Mainz and Basel

Middleton, John, 1983: "One Hundred and Fifty years of Christianity in a Ghanaian town." Africa 53:12-19.

Miller, Jon, 1990: "Class Collaboration for the Sake of Religion: Elite Control and Social Mobility in a Nineteenth-Century Colonial Mission." Journal for the Scientific Study of Religion 29:35-53.

Miller, Jon, 1991: "Institutionalized Contradictions: Social Control and Organizational Trouble in a Nineteenth-Century Colonial Mission." Organization Studies 12:

Missionary Papers for the Use of the Weekly and Monthly Contributors to the Church Missionary Society, London 1816-1867.

Missionary Sketches, London, 1820-1868.

Monats-Blatt der Norddeutschen Missionsgesellschaft, Bremen, from 1840.

Nachrichten aus der Heidenwelt, Stuttgart, 1823-43.

New, Charles, 1873: Life, Wanderings, and Labours in Eastern Africa. London.

Pabst, Martin, 1988: Mission und Kolonialpolitik. Die Norddeutsche Missionsgesellschaft an der Goldkiste und in Togo bis zum Ausbruch des ersten Weltkriegs.

Papers Relative to the Wesleyan Missions and to the State of Heathen Countries (London, from 1820).

Pobee, John, 1986: "Akropong, Stolz der Basler Mission." Zeitschrift für Mission, 219-25.

[Annual] Report of the German Evangelical Mission on the West Coast of India, Mangalore, 1839/41 to 1913. (Despite its title this is a printed English-language annual report of the Basel Mission, largely, but not exclusively, concerned with its work in India)

Roberts, Andrew, ed., 1988: Photographs as Sources for African History. London.

Schöck-Quinteros, Eva, and Dieter Lenz 1986: 150 Jahre Norddeutsche Mission 1836-1986,. Bremen.

Schrenk, Volkmar 1990: Christian Hornberger, ein Oberkochener Missionar, Forschungsreisender und Photograph (1831-81), (duplicated text of a lecture to the Protestant congregation) Oberkochen.

Spieth, Jakob 1906: Die Ewe-Stämme. Berlin. 
Theye, Thomas,ed., 1989: Der geraubte Schatten. Photographie als ethnologisches Dokument.

Ueber die Wichtigkeit der Bewahrung photographischer Kulturzeugnisse (1990)=nos 3/4 of Zeitschrift für Kulturaustaus.

Ustorf, Werner, 1986: Mission im Kontext. Beiträge zur Sozialgeschichte der Norddeutschen Missionsgesellschaft im 19. Jahrhundert. Bremen.

Ustorf, Werner 1989: Die Missionsmethode Franz Michael Zahns und der Aufbau kirchlicher Strukturen in Westafrika, eine missionsgeschichtliche Untersuchung. Erlangen.

Viditz-Ward, Vera 1987: "Pholography in Sierra Leone, 1850-1917." Africa 57:510-17.

Wagner, Wilfried 1990: "Missionare als Photographen" in Zeitschrift fur Kulturaustausch 40:466-74.

West, Thomas 1857: The Life and Joumals of the Rev. Daniel West, Wesleyan Minister on Deputation to the Wesleyan Mission Stations on the Gold Coast, Westem Africa. London.

Wilks, Ivor 1975: Asante in the Nineteenth Century, Cambridge.

Zahn, M., 1864: Die Arbeit der Norddeutschen Missionsgesellschaft. Bremen

Zahn, M., 1865: Einige Bedenken gegen die Mission. Nebst Rechnungen und Uebersichten der Norddeutschen Missionsgesellschaft für 1864

Zahn M., 1866: Rechnungen und Uebersichten der Norddeutschen Missionsgesellschaft fur 1865 .

The last three items are bound into the Basel Mission holdings of $M B$. 